\title{
Radionuclides concentrations in the Loire river system resulting from routine discharges of five nuclear power plants: assessment of dose to man*
}

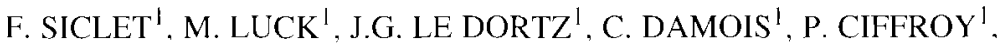 \\ F. HENDRICKX ${ }^{1}$, J.R. COURIVAUD ${ }^{\prime}$
}

(Manuscript received 1st September 2001, acceled 18 September 2002)

ABSTRACT Low level radioactive liquid discharges have been carried out in the Loire river since 1963. Since then, the number of power plants located on the Loire river and its tributaries has been steadily increasing to reach, in the year 2000, 14 reactors operating on 5 different sites. The question arose to evaluate to what extent the addition of several nuclear power plants on the same river system could increase the concentrations in radionuclides in the environment and affect the dose to the public. To address this issue, FIP initiated in 1998 the "Loire river and estuary radioccology" program with the focus on assessing possible accumulation of radionuclide in river botton sediments or on river shores. The following radionuclides were considered because of their importance in power plant liquid discharges: tritium, ${ }^{14} \mathrm{C},{ }^{58} \mathrm{Co},{ }^{60} \mathrm{Co},{ }^{110 \mathrm{~m}} \mathrm{Ag},{ }^{134} \mathrm{Cs},{ }^{137} \mathrm{Cs},{ }^{54} \mathrm{Mn},{ }^{124} \mathrm{Sb}$, and ${ }^{131} \mathrm{I}$. Radionuclide concentrations in the dissolved, particulate and sedimentary forms were evaluated using the CRESCENDO model. The development and validation of this model required a multi-step process. The first step was to design a $350-\mathbf{k m}$ long $1 \mathrm{D}$ hydraulic and water transport based on currently available tools and data. Next, daily tritium concentrations measured in Angers, at the downstream limit of the river, were compared with computed values. The following step was to calibrate the sediment transport model. Areas where fine particles settled (dams and river shores) were monitored to improve our understanding of sediment dynamics. Then equations representing radionuclide exchange between water and particles were derived from laboratory experiments and included in the model. After each step the computed values were compared to measure data sets to ensure the model adequately described the processes involved. In the final step, the CALVADOS model was used to calculate dose to the public at different locations along the I.oire river.

RÉSUMÉ Concentration de radionucléides dans la Loire résultant des rejets de cinq sites nucléaires : évaluation de dose à l'homme.

Des rejets liquides de faible radioactivité ont eu lieu depuis 1963 dans la Loire. Le nombre de centrales implantées sur la Loire et ses affluents a augmenté

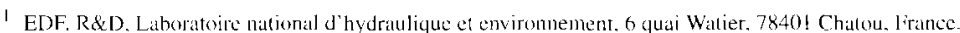

Cel arricle accompagnatit le poster présenté au congress « The Radioecology-Fooloxicology of Continental and Futuarine

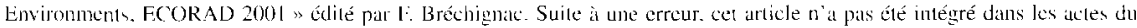
colloque (Radioprotection-collowues, volume $37, \mathrm{C} .1$ ). Nous le reproduisons done ici dans son intégralité, avec nos exeuses aux auleurs.
} 
régulièrement depuis cette date jusqu'à atteindre, en 2000,14 réacteurs sur 5 sites différents. Il est donc devenu important d'évaluer si l'implantation de plusieurs centrales sur le même réseau hydrographique était de nature à augmenter les concentrations de radionucléides dans I'environnement avec répercussion sur les doses reçues par le public. C'est pour répondre à cette question que EDF a entrepris en 1998 le programme « Radioécologie Loire et estuaire » avec un accent particulier sur l'examen de l'accumulation potentielle de radionucléides dans les sédiments de fond ou sur les rives. La liste suivante de radionucléides a été considérée eu égard à leur présence dans les effluents liquides des centrales : tritium, ${ }^{14} \mathrm{C},{ }^{58} \mathrm{Co},{ }^{60} \mathrm{Co}$, ${ }^{110 \mathrm{~m}} \mathrm{Ag},{ }^{134} \mathrm{Cs},{ }^{137} \mathrm{Cs},{ }^{54} \mathrm{Mn},{ }^{124} \mathrm{Sb}$ et ${ }^{131} \mathrm{I}$. Les concentrations de radionucléides sous forme dissoute, particulaire ou dans les sédiments ont été estimées en utilisant le modèle CRESCENDO. Le développement et la validation de ce modèle ont été entrepris selon un processus multi-étapes. La première étape a consisté à bâtir un modèle $1 D$ d'hydraulique et de transport dans l'eau, sur une longueur de $350 \mathrm{~km}$, à partir des outils et des données déjà disponibles. L'étape suivante a consisté à comparer les concentrations journalières en tritium mesurées à Angers, c'est-à-dire à l'aval du fleuve, avec les valeurs calculées. Le modèle de transport sédimentaire a ensuite été calibré. Les zones de sédimentation des particules fines (barrages et rives) ont été particulièrement suivies pour améliorer la compréhension de la dynamique sédimentaire. Ensuite, les équations décrivant la partition des radionucléides entre l'eau et les particules ont été déterminées à partir d'expériences au laboratoire et introduites dans le modèle. À chaque étape, les valeurs calculées ont été comparées à des séries de données mesurées pour s'assurer de la bonne représentation par le modèle des processus impliqués. Enfin, en étape finale, le modèle CALVADOS a été utilisé pour calculer les doses reçues par le public à différents emplacements le long de la Loire.

\section{Introduction}

Routine operation of nuclear power plants produces liquid radioactive effluents which are treated for decontamination and intermittently released in rivers or in the sea, when radioactivity levels are sufficiently low, in compliance with regulations. Environmental monitoring around EDF power plants shows, in accordance with modeling results, that the operation of these plants, even over a long period, results in very low artificial radioactivity levels in the aquatic and terrestrial environment. However, at a larger scale, encompassing an entire river system with several nuclear power plants, the question arose to evaluate to what extent the multiple discharges of low level radioactive liquid wastes on the same river basin could increase the concentrations in radionuclides in the environment and affect the dose to the public. Special attention was to be given to mechanisms responsible for accumulation of radionuclides in specific locations, such as low water velocity areas where fine particles are deposited over long time periods and resuspended only at high flow regimes.

The Loire river and its tributaries where five EDF nuclear power plants are operating was chosen as a test case to address this issue (Fig. 1). To be able to cover long time periods, different flow regimes and all locations of interest along the river basin, computer modeling was required. The CRESCENDO model was 


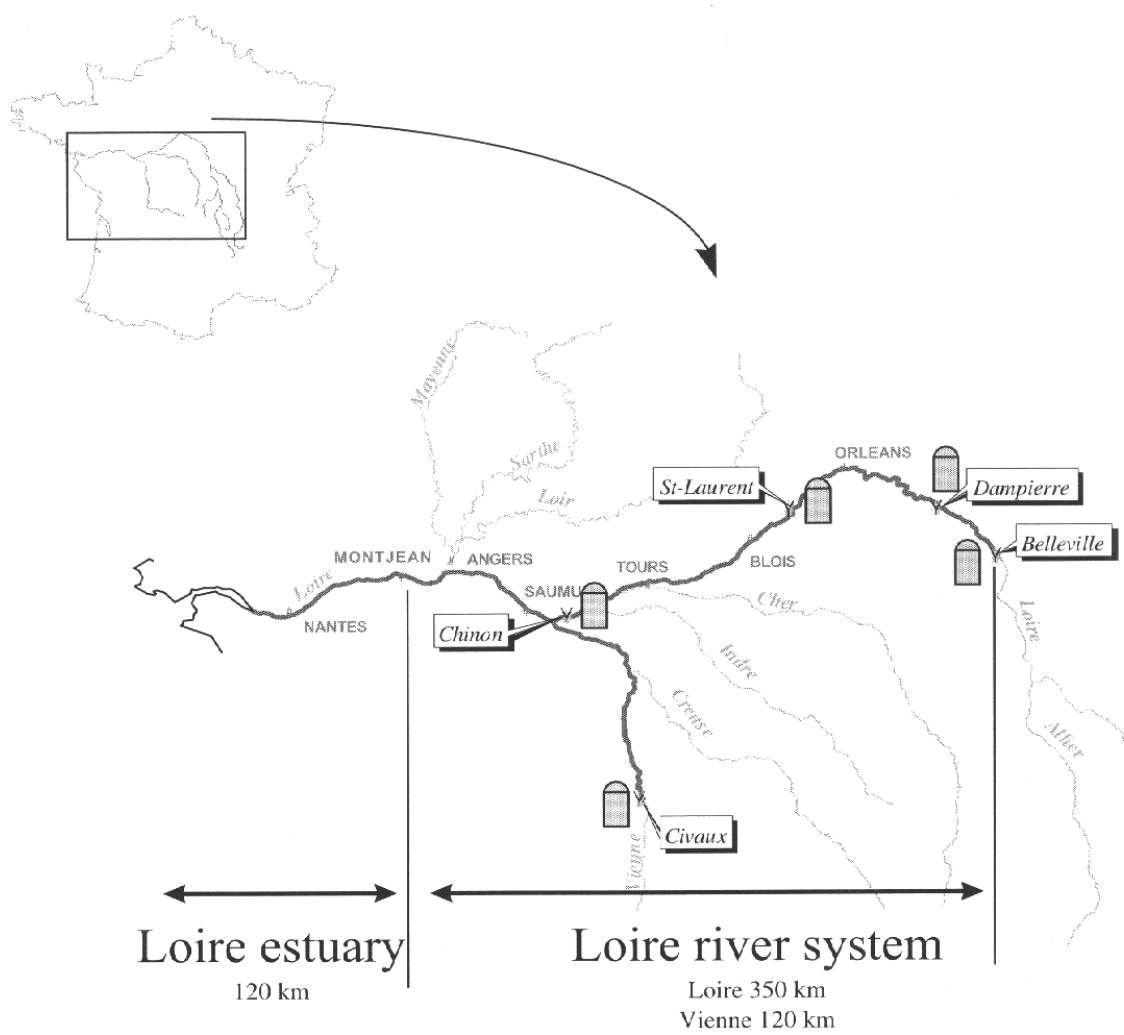

Figure 1 - Location map of the Loire river system and its tributaries. The reaches included in this study are represented by bold lines, NPP and the major cities where radiological dose to man was calculated are indicated.

Carte géographique de situation de la Loire et ses affluents. Les tronçons inclus dans cette étude sont identifiés en gras, et l'implantation des centrales nucléaires ainsi que les principales villes ayant fait l'objet d'un calcul de dose à l'homme sont indiquées.

developed to evaluate radionuclides concentrations in the dissolved, particulate and sedimentary forms and the CALVADOS model was implemented to calculate concentrations along the food chain and the dose to man. Development and implementation of these radioecological models required not only specific radioecological experiments (for example to determine $\mathrm{Kd}$ and kinetics parameters of radionuclide exchange between water and suspended matter), but also a concentrated effort at data collection in the field (detailed suspended solids timeseries, monitoring of deposit and erosion at selected locations, monitoring of 
radionuclide concentrations in water and sediments, survey of agricultural practices) either to calibrate or to validate the models.

This presentation briefly reviews the characteristics of the models and highlights some of the results of a six-year-simulation.

\section{The CRESCENDO model}

The global model is subdivided in coupled and uncoupled sub-models (Fig. 2).

Three coupled sub-models are used:

the hydrodynamic sub-model: a fully complete 1D hydraulic model named LIDO which solves free surface flow equations in rivers was used. The natural form of the river is considered by LIDO which requires a very accurate bathymetry of the river (data on main section profiles);

- the transport sub-model: using the results of the hydraulic model, TRACER simulates the ID transport and dispersion of dissolved substances, or solids. The processes of sedimentation and erosion are modeled by the classical laws of Krone and Partheniades:

- the exchange sub-model describes the exchanges of radionuclides between the dissolved and the particulate phases. The exchanges are modeled using kinetic equations for two step reversible reactions which lead to equilibrium characterized by the distribution coefficient $K_{d}$. In situ and laboratory experiments were conducted to determine these parameters for the Vienne and Loire river, in summer and in winter.

Sedimentation on riverbanks, although important with respect to radiological assessment, was not included in the coupled radionuclide transport model, because it was not essential for the mass balance of radionuclides in rivers. It was decided to develop uncoupled sub-models, using the data from the coupled sub-models, to estimate shore sediment deposit as well as radionuclide concentrations in the partially mixed region close to the power plant release point.

\subsection{Calibration and validation of the hydraulic and transport models}

In order to calibrate the friction coefficients, a very detailed data base on water levels for low, medium and high flow regimes, gathered by DIREN (Directions régionales de l'environnement) Centre, was used. Comparison with several tracings of the river provided validation of the mathematical modeling of river velocity. To calibrate the dispersion coefficient and validate the hydraulic and dissolved substances transport models, water samples were collected every 8 hours in the downstream section of the river basin (in the city of Angers) and analyzed for tritium concentrations. An example of validation where predictions are compared to observed values is presented in Figure 3. 


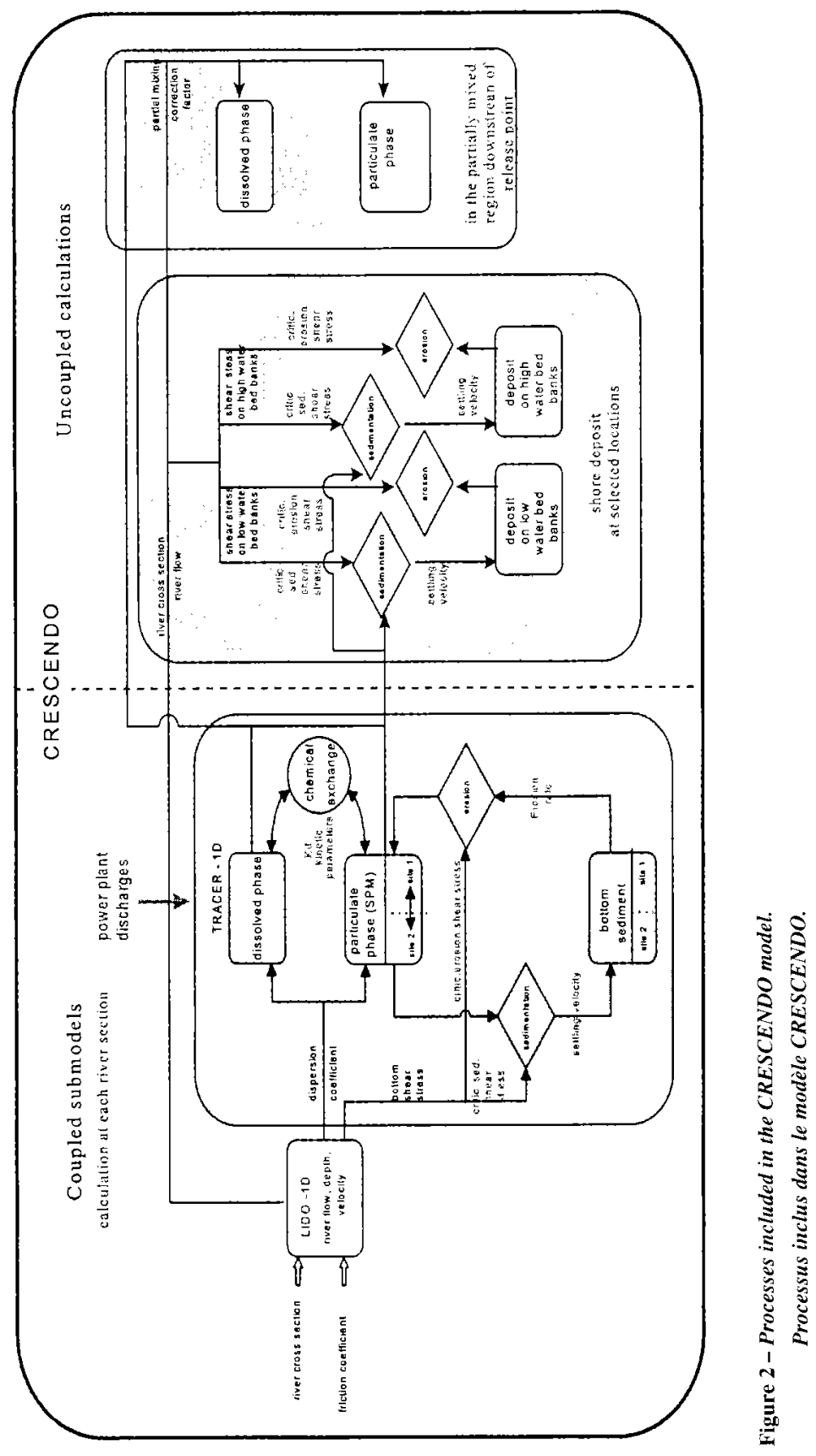




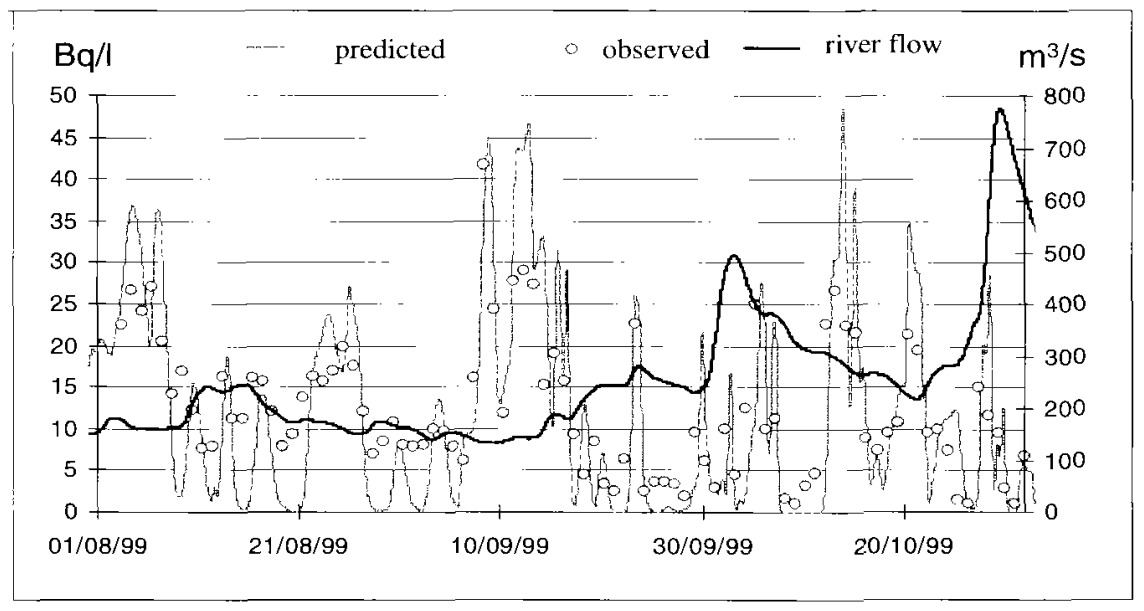

Figure 3 - Observed and predicted values of tritium concentrations in Angers.

Cońcentrations en tritium observées et simulées à Angers.

\subsection{Calibration of the sedimentation and erosion parameters}

The Blois dam, one of the only location along the middle reaches of the Loire river, where settling of fine particles occur, was selected as the study site for sediment transport. The Blois dam is raised every summer to maintain a constant water level for recreational activities.

Thickness of sediment deposits in the Blois reservoir was evaluated from cores collected in summer 1999 and suspended particulate matter (SPM) concentrations were measured in the fall 1999, upstream and downstream of the reservoir when the dam was lowered. Because of the transversal and longitudinal heterogeneity of the sediment deposit, a two-dimensional numerical model, the TELEMAC-2D model, was used. This model coupled with SUBIEF-2D solves the shallow water equations of fluid flow as well as transport and diffusion equations. It allows calculating, for suspended solids, sedimentation and erosion fluxes. The $2 \mathrm{D}$ model was calibrated against observed thickness of sediment deposit and observed concentrations in SPM during the resuspension event of October 26, 1999. The results of the 2D model (predicted sediment deposit, and predicted SPM concentrations) were then used to calibrate the CRESCENDO model (bottom sediment sub-model and the shore deposit calculations). 
Benne

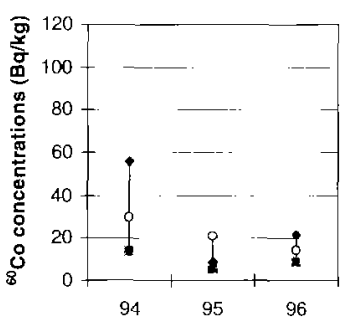

Muides

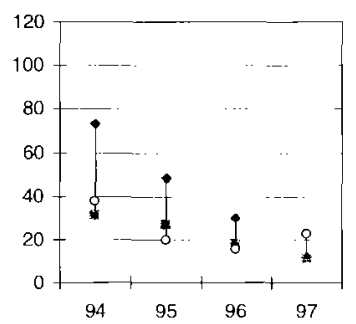

Bertignolles

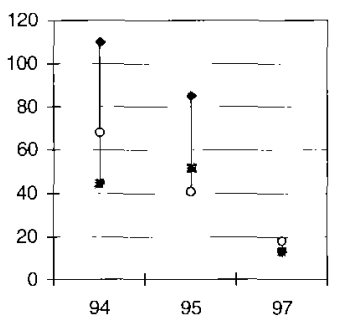

- measured value normalized to clay

- measured value normalized to fine silt+clay

o calculated value

Figure 4-Observed and predicted ${ }^{60}$ Co concentrations in shore deposits, from 1994 to 1997 , in Benne (downstream of Dampierre NPP), in Muides (downstream of St-Laurent NPP) and in Bertignolles (downstream of Chinon NPP).

Concentrations observées et prédites en ${ }^{60}$ Co dans les dépôts des berges, de 1994 à 1997, à Benne (aval de la centrale de Dampierre), à Muides (aval de St-Laurent) et à Bertignolles (aval de Chinon).

\subsection{Validation of the shore deposit calculations}

Concentrations observed in shore sediments collected in the annual radioecological monitoring program of each power plant site were compared to predicted values. Since the model calculates the activity associated to fine particles, observed values were corrected considering that the radioactivity present in a sediment sample is associated only to the clay and/or fine silt fraction. Figure 4 shows the cobalt- 60 concentrations in shore sediment demonstrating that the predicted values lay within the range of the observed concentrations.

\section{CRESCENDO results - Simulation from 1994 to 1999}

\subsection{Spatial evolution of radionuclide concentrations along the Loire and Vienne rivers}

Average tritium concentrations increase along the Loire river from the Belleville NPP to the Saint-Laurent NPP: this reach of the river receives effluents from 3 power plants without any significant water input by tributaries. The highest 


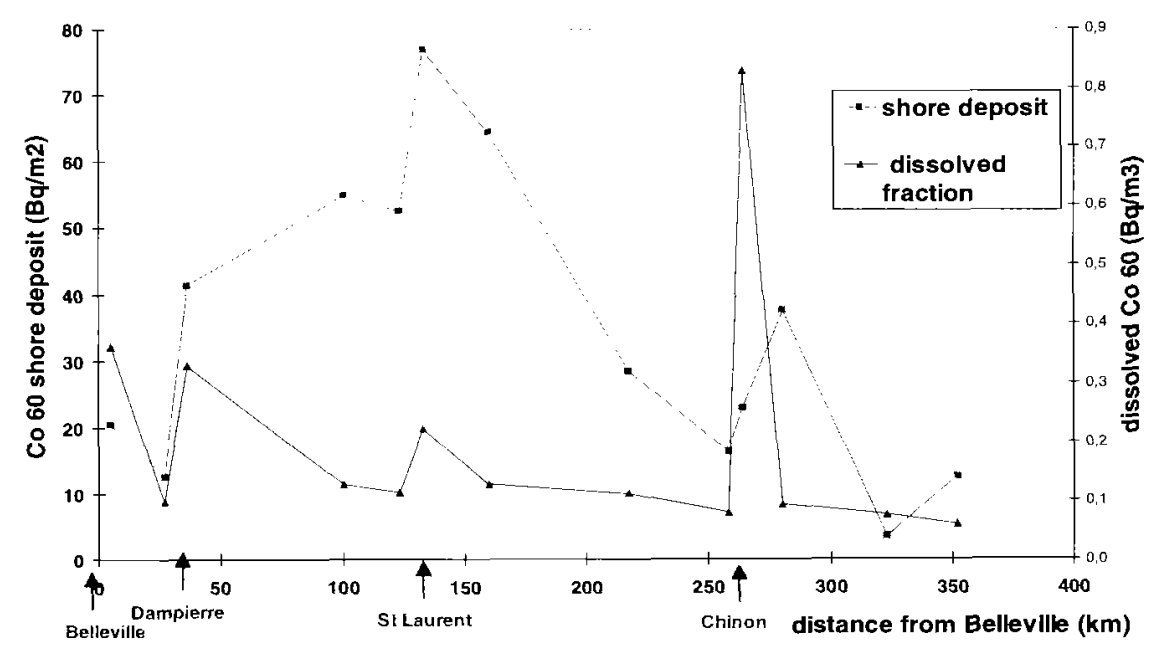

Figure 5 - Spatial distribution of ${ }^{60}$ Co in dissolved fraction and in shore deposits (1994 to 1999 average values).

Distribution spatiale de la concentration en ${ }^{60}$ Co sous forme dissoute et dans les dépôts des berges (valeurs moyennes de 1994 à 1999).

concentrations (yearly average of $12 \mathrm{~Bq} / \mathrm{l}$ ) are observed in the $100-\mathrm{km}$ region between St-Laurent NPP and the Cher river confluence. After a sharp decrease downstream of the confluence, tritium concentrations reach a peak in the $7-\mathrm{km}$ reach between Chinon NPP and the Vienne river confluence and decrease hereafter down to the estuary. Large variations are observed from one month to another in relation to water flow and radioactive effluent management.

Other dissolved or particulate radionuclides show the same overall spatial evolution, although slight differences are observed due to the enhanced sorption of radionuclide on particles with increasing contact time. The distribution pattern of radionuclides in sediment differs greatly from the distribution in river waters (Fig. 5). The main factor controlling sediment deposit is clearly local topography of the riverbed and to a lesser extent radionuclide concentration in the river water.

\subsection{Sediment remobilization}

Sediment deposits are washed out yearly on the Loire river. Simulation of a resuspension event in Blois shows that there is a peak in particulate radionuclide concentration during the sharp increase in suspended matter concentrations, but the specific activity of the remobilized sediment is lower than the specific activity 
TABLFI

Major contribution to individual dose in Blois (average from 1994 to 1999) (n.c.: not calculated). Contribution majoritaire à lá dose individuelle à Blois (moyenne entre 1994 et 1999) (n.c. : non calculé).

\begin{tabular}{|c|c|c|c|c|c|}
\hline dose $(S v / y)$ & ${ }^{60} \mathrm{Co}$ & 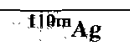 & ${ }^{137} \mathrm{Cs}$ & $\therefore \mathrm{C}$ & 34 \\
\hline shore sediment & $9.4 \times 10^{-8}$ & $1.5 \times 10^{7}$ & $3.2 \times 10^{9}$ & - & - \\
\hline water & $1.9 \times 10^{-10}$ & $1.4 \times 10^{10}$ & $58 \times 10^{-10}$ & $1.5 \times 10^{9}$ & $1.1 \times 10^{-7}$ \\
\hline fish & $1.3 \times 10^{-4}$ & $1.7 \times 10^{11}$ & $2.8 \times 10^{8}$ & $8.5 \times 10^{-8}$ & $2.2 \times 10^{8}$ \\
\hline irrigated vegetibles & $1.0 \times 10^{9}$ & $1.2 \times 10^{-9}$ & $7.8 \times 10^{-9}$ & n.c. & $5.5 \times 10^{-k}$ \\
\hline milk & $1.4 \times 10^{11}$ & $1.1 \times 10^{-10}$ & $1.2 \times 10^{-10}$ & n.c. & $2.7 \times 10^{-4}$ \\
\hline meal & $5.3 \times 10^{-11}$ & $1.4 \times 10^{-11}$ & $1.7 \times 10^{10}$ & n.c. & $1.5 \times 10^{.8}$ \\
\hline total & $9.7 \times 10^{-8}$ & $1.5 \times 10^{-7}$ & $4.0 \times 10^{-8}$ & $8.6 \times 10^{-8}$ & $2.1 \times 10^{-7}$ \\
\hline
\end{tabular}

of SPM during the transit of a radioactive release (Fig. 6). There was no significant increase in dissolved concentration which remained lower than during a radioactive release. It demonstrates that sudden erosion of sediment accumulated in reservoir results in a short duration increase of particulate radionuclide concentration but does not increase dissolved radionuclide concentrations or radionuclide in sediment deposited downstream.

\section{The CALVADOS model}

CALVADOS is a dynamic food chain model which evaluates the radiological impact of radioactive releases in rivers. It simulates with a monthly time step the pathways leading to internal or external exposure: transfer through the aquatic food chain to fish, transfer due to agricultural river usage for irrigation and cattle drinking water, internal exposure due to ingestion of water, fish, and agricultural foodstuffs, internal exposure due to inhalation of dust originating from resuspension of irrigated soil particles, external exposure from radionuclides in river water, on river sediments and on irrigated soils. It takes into account seasonal variability in river regimes, agricultural practices and human habits.

Among the radionuclides released by nuclear power plants, the highest dose contributions (Tab. I) could be attributed to tritium through water ingestion (1.2 liter daily), carbon-14 through river fish consumption (30-g daily), silver$110 \mathrm{~m}$ and cobalt -60 through shoreline recreational activities ( $10 \%$ of the day). The agricultural pathways (through crop irrigation and cattle drinking water) contribute weakly to the total dose.

Differences between stations are linked to shore deposit estimates and partial mixing in the region close to the release. They are lower than one order of 
F. SICLET et al.

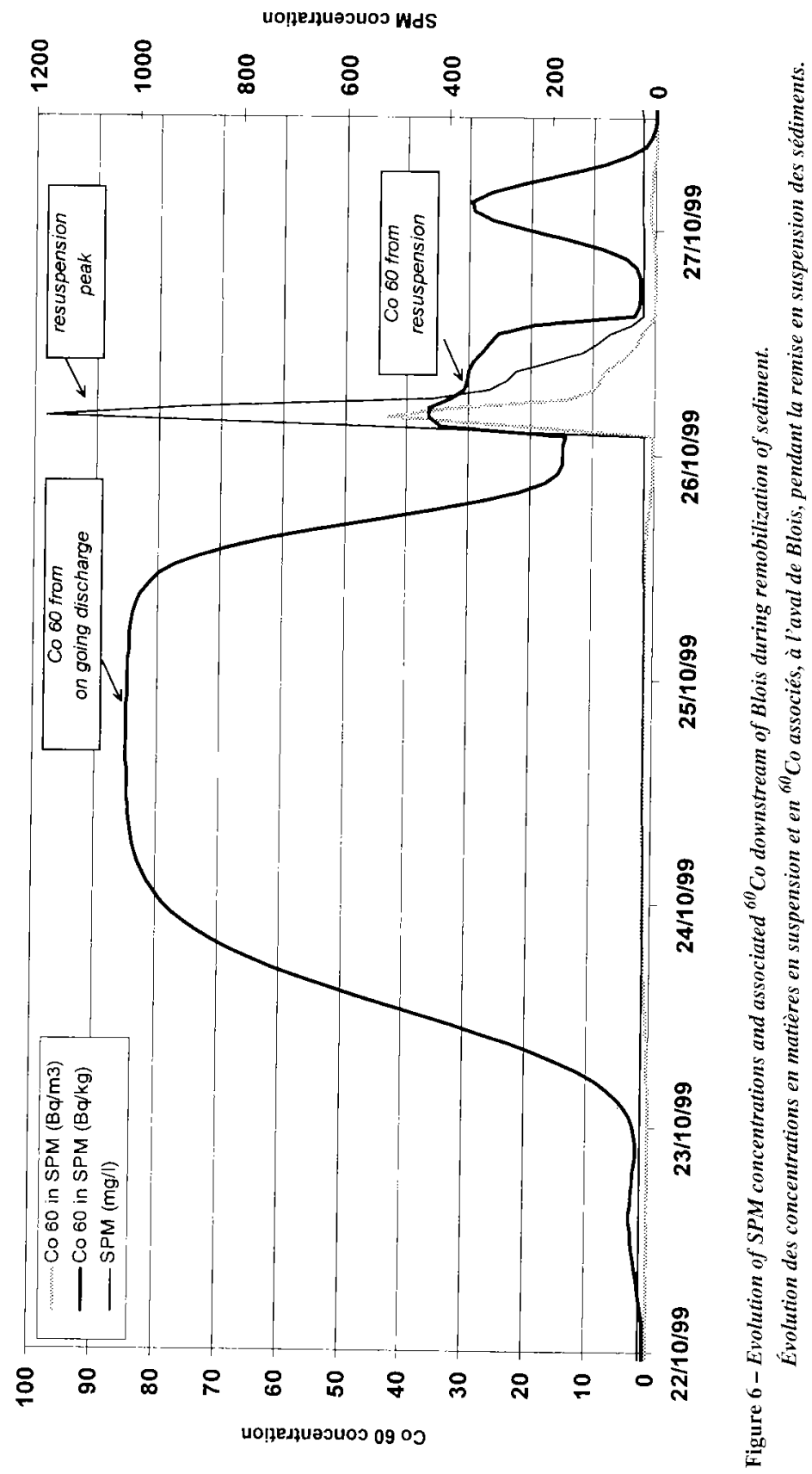




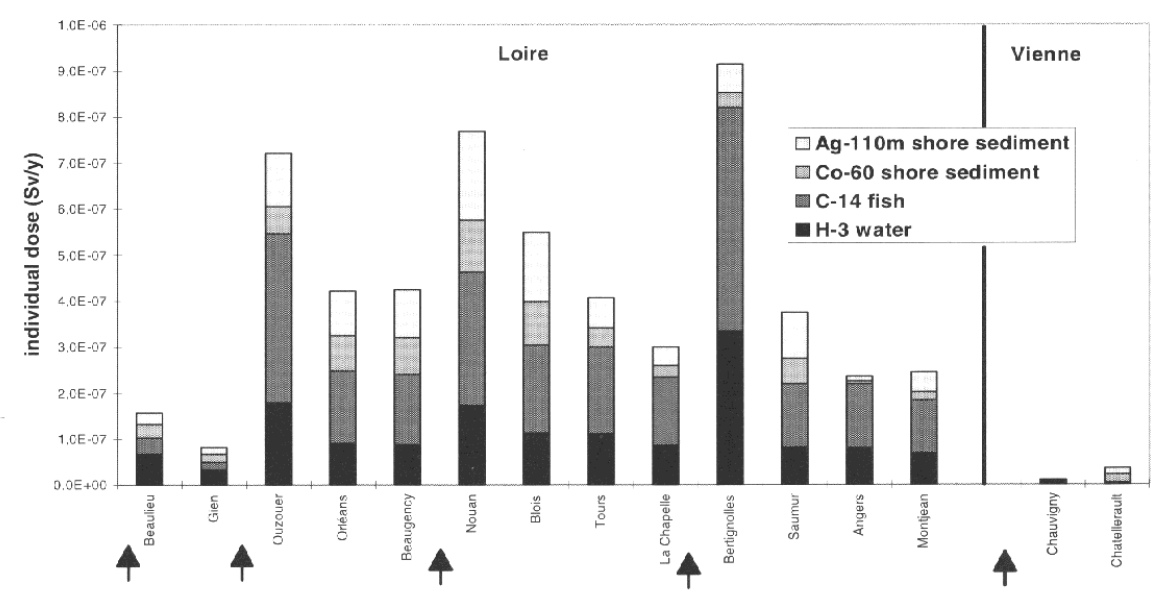

Figure 7 - Prediction of average dose due to liquid releases of NPP on the Loire and Vienne rivers (arrows represent power plants release).

Prédiction de la dose moyenne induite par les rejets liquides des centrales implantées sur la Loire et la Vienne (les flèches indiquent les points de rejet).

magnitude between the most exposed areas in the mixing zone and the least exposed stations between the Belleville and Dampierre NPP (Fig. 7).

\section{Conclusions}

The CRESCENDO model proved to be a valuable tool in addressing the issue of radionuclide transfer at the river basin scale. Except in the partially mixed region downstream of each power plant where peak concentrations are observed, the general trend in dissolved and particulate radionuclide concentrations is to remain rather constant along the river, due to dilution from tributaries that compensate for the radioactive input from power plants. The distribution pattern of radionuclides in bottom sediment and on riverbanks differs greatly from the distribution in river waters, the main reason for the wide variations in sediment deposit being clearly local topography of the riverbed.

Dose evaluation with the CALVADOS model through ingestion and external exposure due to power plant liquid releases varies between 0.1 and 1 microsievert per year depending on the location. The highest contributions can be attributed to tritium through water ingestion, carbon-14 through river fish consumption, silver$110 \mathrm{~m}$ and cobalt- 60 through shoreline recreational activities. 
The sedimentation process on riverbanks must be considered as the most sensitive pathway from which high dose variations may be expected. The external exposure due to radioactive discharges remains nevertheless very low compared to the contribution due to natural radionuclides $\left({ }^{40} \mathrm{~K},{ }^{226} \mathrm{Ra}\right.$ and $\left.{ }^{232} \mathrm{Th}\right)$ on river banks which amounts to 50 microsievert per year. The predicted total dose due to nuclear power plant liquid releases is far below the legally admissible dose limit to the public of 1 millisievert per year. 